1.はじめに

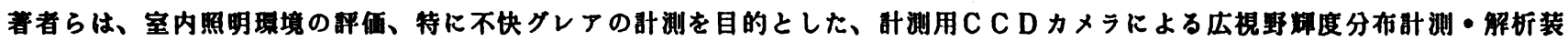

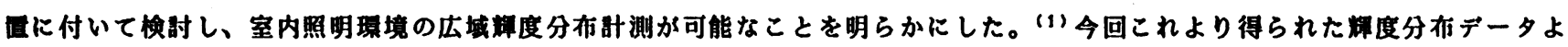
り光源を抽出し、それそれの光源ことにその位固、戦度、立体角を算出するアルコリズムについて検时した。

\section{2. 瓶度分布の测定}

システムは、図1に示すような柈成となる。

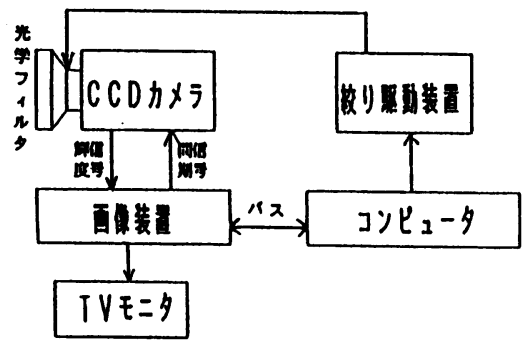

\begin{tabular}{|c|c|}
\hline $\operatorname{cco} \pi x y$ & 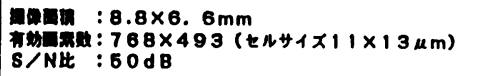 \\
\hline レンx & 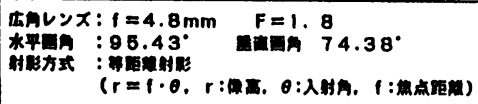 \\
\hline 光乎フィルタ & 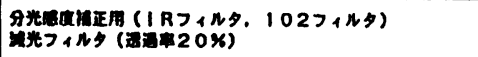 \\
\hline Enate & 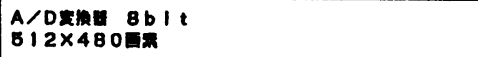 \\
\hline コンヒュータ & 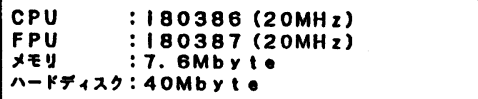 \\
\hline
\end{tabular}

図1・システム

C C D カラは、光学フィルターにより梘感度铺正され、㸎 度に比例した信号を出力する。この信号を画像装圈に取り込む。 画像装固と、コンピュータはパス接綂されており、コンピュー

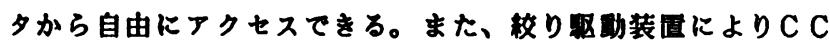
Dカメラの感度を钼化することがでる。

一般の室内の端度分布は、数 $\left[\mathrm{cd} / \mathrm{m}^{2}\right] \sim$ 数干 $\left[\mathrm{cd} / \mathrm{m}^{2}\right]$ に分布し ており、C C D カラのタイナミックレンジ (約1.5decade )

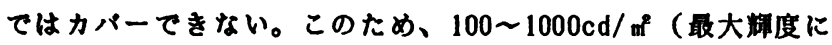
より自動的に变化する）を境に、高辉度用と低弾度用の 2 種類 の较り (レンジ) で覃度データを得る。このとき 20 画面サン ブリングし、その加算平均を彈度データとしている。この輝度 データから、システムの暗流分とレンズのローカリティ（周边 光量の低下) の㭪正を行う。

\section{3.光源の抽出と各光源の、位冝、輝度、立体角の算出}

光源の抽出には高潼度用データを用い、あるスレッシロルド レベルを越える画素を光源とみなし、ラベルをつけることで、 光源を抽出する。実际には、図2（a）のように、高详度デー タをラスタ操作し、1ライン上で新たに光源（スレッショルド レベルを越える画素）か現れる度にラベルを付ける。次のラ1 ンでは、前のラインと重なりがあれば、同じラベルを付ける。 2つ以上のラベルが合流した场合、これらが同一であるとみな し、挠で付け直す（図2（b））。

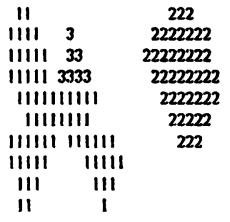

(a)
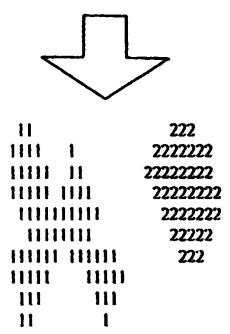

(b)

図2.ラベル付け
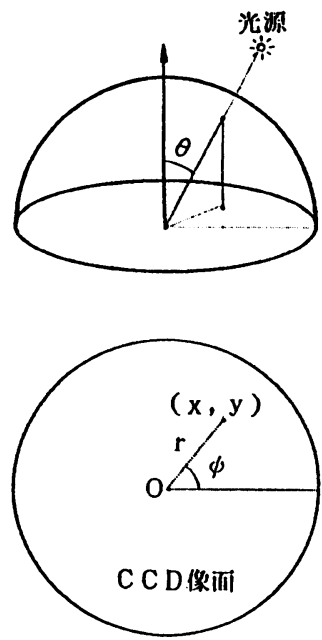

图 3. 等距踓射影
このシステムで探用したレンズは、等距離射影方式のため、

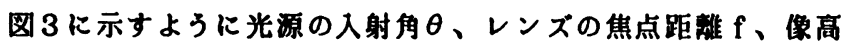
$\mathrm{r}$ とすると $\mathrm{r}=\mathrm{f} ・ \theta$ の關がある。像の座標 $(x, y)$ とす ると、 $r=\sqrt{x^{2}+y^{2}}$ なので、

$$
\theta=\sqrt{\mathrm{x}^{2}+\mathrm{y}^{2}} / \mathrm{f}
$$

となる。また偏角 $\phi$ は、

$$
\phi=\mathrm{ta} \mathrm{n}^{-1}(\mathrm{y} / \mathrm{x})
$$

である。これを 1 画素毎にすとめ、同一ラベルに付いて平均す ることにより、光源の位冝 $(\theta, \psi)$ を求める。

1 画秦の面積 $\Delta s$ の張る立体角 $\Delta \omega$ は、 


$$
\Delta \omega=\frac{\mathrm{sin} \theta}{\theta} \cdot \frac{1}{\mathrm{f}^{2}} \cdot \Delta \mathrm{s} \quad \cdots
$$

で表される。これを同じラベルに付いて加算することにより、 光源の立体角 $\omega$ を求める。各光源の平均輝度はそのラベルこと に画素の籍度の加算平均で求的る。

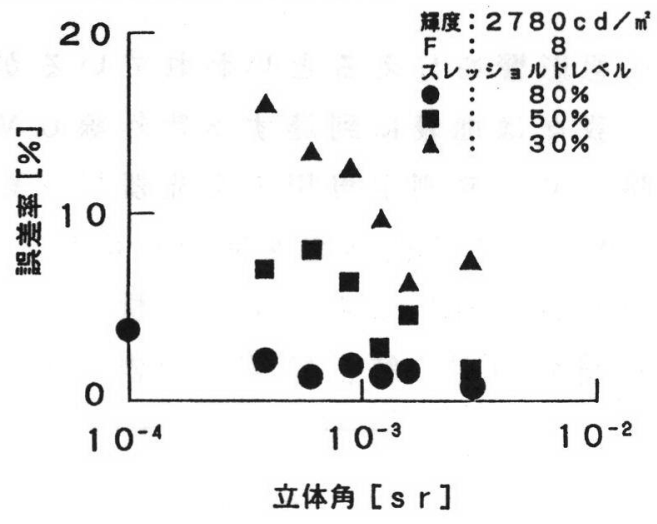

( a ) 輝度の䐣差率

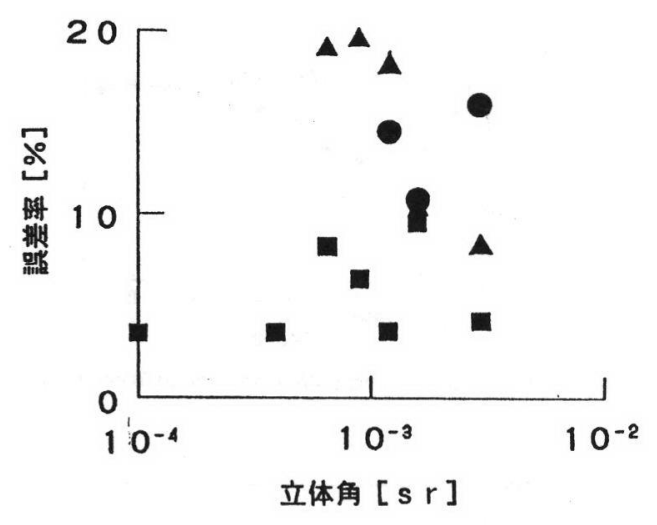

(b) 立体角の㗐差率

図 4. 立体角に対する諆差率

つぎに、白色蛍光灯を内藏した $5.5 \mathrm{~cm}$ 四方の正方形の均一光 源を距離（立体角）を变えて計測した。この輝度データから、 スレッショルドレベル $30 \%, 50 \%, 80 \%$ で光源を抽出し、辡度と立 体角の測定俱差を求めた。その一例が図 4 て、、図 4（a）が耀 度、图 4 （b）が立体角に関するすのでこの図より、50\%のス レッショルドレベルを探用すると立体角 $4 \times 10^{-4} \mathrm{sr}$ 以上の籍囲

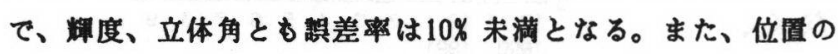
韻差は最大で $1.5^{\circ}$ である。

つぎに、実際の室内輝度分布データの解析した例を、図5に 示す。図5（a）は、高缚度用辡度分布データである。このデ 一タからラベル付けにより、光源を抽出した䊅果が、図 $5(b)$ である。この図から、各光源が抽出され、それぞれに番号がつ いていることが分かる。このとき各光源のごとに、スレッショ ルドレベルをその光源の最大彈度の50\% とするために、次の操
作を行った。

1) 視野内の最大变度の5\%をスレッショルドレベルとし、ラベ ル付けにより光源を抽出する。

2）各光源を構成する画素のうち、その最大踭度の50\%未满の 画素のラベルを削除する。

3）2）の操作により、光源数が翼なってくることがある（近 い位直にあるため、1 個に見なされていた複数の光源か、 別々に見なされる。）ため、ラベルをつけ直す。

4 ）ラベル数が一定になるまで、2）～3）を綝り返す。

このデータに、（1）〜（3）式を用いることにより、例え ば 4 番目の光源の位置 $(\theta, \phi)=\left(25.8^{\circ}, 64.1^{\circ}\right)$ 、彈度 $5426 \mathrm{~cd} / \mathrm{m}^{2}$ 、立体角 $1.8 \times 10^{-3} \mathrm{sr}$ というように、光源ことに、位 圈、輝度、立体角が自動的に求まる。

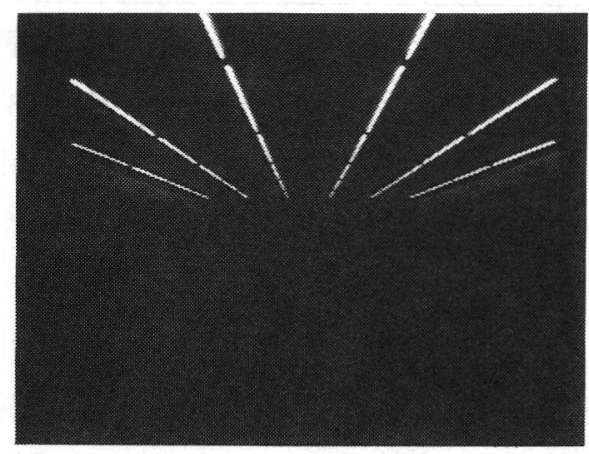

(a) 高耀度用瀷度分布データ

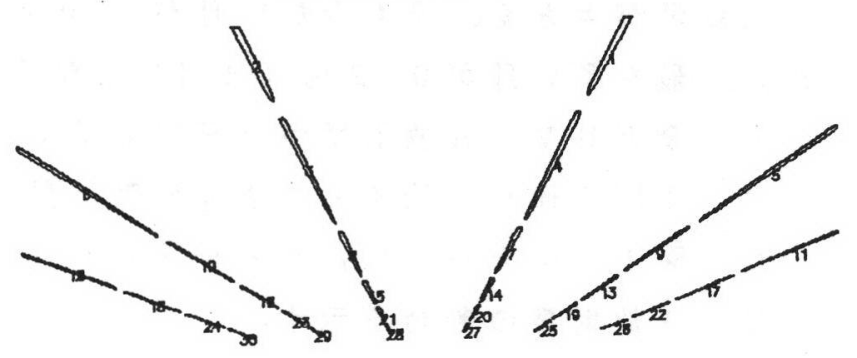

(b) 抽出された光源

図5.実際の室内の解析例

4.おわりに

今回考案したアルコリズムにより、耀度分布データからそれ ぞれの最大㪴度の50\% 以上の画素にラベルをつけて光源を抽出 し、その位直、戦度、立体角を求めることができた。

なお、実験を行うに際して、こ助言を頂いた室井徳雄日本大 学名誉教授に感堙する次第である。

〈参考文献〉

（1）佐々木, 他：計测用 C C D カメラの広視野耀度分布計測・ 解析装固への応用, 電気学会全国大会予稿集 64 p 1-79 (平成 3 年) 